\title{
Adherence of staphylococci to intravascular catheters
}

\section{K. G. KRISTINSSON}

Department of Bacteriology, Royal Hallamshire Hospital, Sheffield S10 2JF

\begin{abstract}
Summary. Adherence of seven strains of Staphylococcus epidermidis and three strains of $S$. aureus to three types of intravascular catheters was assessed by ATP bioluminescence, by culture after ultrasonication and by scanning electronmicroscopy. The catheter materials studied were silicone elastomer, thermoplastic polyurethane and polyurethane coated with Hydromer $^{\circledR}$, a coating which absorbs water and provides a hydrophilic sheath around the catheter. The adherence assays were performed in phosphate-buffered saline on a rotary shaker at $37^{\circ} \mathrm{C}$, with the catheters precoated with serum and uncoated, and the results were correlated with bacterial hydrophobicity. There was wide strain-to-strain variation in bacterial adherence; $S$. aureus and slime-producing $S$. epidermidis strains adhered better than did non-slimeproducing strains. Overall, there was less bacterial adherence to Hydromer ${ }^{\circledR}$-coated catheters than to polyurethane and silicone catheters but it was unrelated to bacterial hydrophobicity. Serum coating of catheters resulted in marked reduction of bacterial adherence.
\end{abstract}

\section{Introduction}

Intravascular catheters are essential in the management of acutely ill patients. Long intravenous lines are often left in situ for long periods to maintain infusions of hyperosmolar fluids and drugs and for haemodynamic monitoring. Silicone catheters (Hickman ${ }^{\circledR}$ and Broviac $^{\circledR}$ ) are widely used to maintain long-term intravenous access in patients with haematological malignancy and in patients on total parenteral nutrition. The major complication of prolonged intravascular catheterisation is infection, leading to bacteraemia that may be lifethreatening (Sheretz et al., 1983). Press et al. (1984) quoted an average infection rate of $0 \cdot 14 / 100$ catheter days.

The intravascular portion of a catheter is encased by fibrin within 5-7 days (Hoshal et al., 1971) and catheter thrombosis is a major risk factor in the development of catheter infection (Press et al., 1984). Thrombogenicity is associated with the stiffness (Stenqvist et al., 1983) and the nature (Borow and Crowley, 1985) of the catheter material.

Catheter manufacturers have concentrated mainly on making biocompatible catheters with a low thrombogenic potential, rather than catheters with antibacterial properties. However, bacterial

Received 17 June 1988; accepted 1 Sep. 1988.

Address for correspondence: Dr K. G. Kristinsson, Department of Microbiology, University of Iceland, Baronstig, PO Box 1465, 121 Reykjavik, Iceland. adherence is important in the initial stages of infections of prosthetic devices (Peters et al., 1982) and coagulase-negative staphylococci (CNS) and Staphylococcus aureus are the commonest organisms causing such infections (Press et al., 1984; Sattler et al., 1984; Harvey et al., 1986). The aim of this study was to investigate the initial adherence of CNS and $S$. aureus to two commonly used catheter materials, silicone and polyurethane, and to compare these with the adherence to polyurethane coated with Hydromer ${ }^{\circledR}$, which makes surfaces more hydrophilic and reduces thrombogenicity (Borow and Crowley, 1985; Seifert and Greer, 1985).

\section{Materials and methods}

\section{Bacteria}

Three $S$. aureus strains $(\mathrm{C} 710, \mathrm{C} 1583, \mathrm{C1662})$ and four S. epidermidis strains (C1276, C1543, A1085, A2057) were isolated from infected long intravenous catheters in the Bacteriology Department, Royal Hallamshire Hospital, Sheffield. S. epidermidis strain KH11 was from Professor G. Peters, Hygiene Institute, Cologne, West Germany. Two S. epidermidis strains (C362, C988) isolated as skin commensals were also included. Four of the $S$. epidermidis strains produced extracellular slime as detected by the method described by Christensen et al. (1982). All strains were stored at $-20^{\circ} \mathrm{C}$ in glycerol $10 \% \mathrm{v} / \mathrm{v}$ broth. They were cultivated overnight at $37^{\circ} \mathrm{C}$ in Tryptone Soy Broth (TSB, Oxoid) when required. 
Strains were harvested by centrifugation, washed twice in 10-ml volumes of phosphate-buffered saline (PBS, $\mathrm{pH}$ $7 \cdot 4$ ), and resuspended in PBS by vortex mixing. The bacterial suspension was filtered through membrane filters (type NC $14.0 \mu \mathrm{m}$, Millipore Co., MA, USA) to remove clumps and adjusted to a density of $(0 \cdot 5-1) \times 10^{9}$ $\mathrm{cfu} / \mathrm{ml}$ by optical-density measurement at $540 \mathrm{~nm}$ $\left(\mathrm{OD}_{540}\right)$ and calibrated by viable counts. The slimeproducing strains of $S$. epidermidis were treated by ultrasonication (12 m peak-to-peak, for $1 \mathrm{~min}$; MSE ultrasonic disintegrator) before filtering.

\section{Measurement of hydrophobicity}

Bacterial hydrophobicity was assessed by measuring adherence to xylene in an aqueous phase (Rosenberg, 1984). Analytical grade $p$-xylene $(0.25 \mathrm{ml})$ was added to $3 \mathrm{ml}$ of the bacterial suspension that had been adjusted to an $\mathrm{OD}_{540}$ of $1.0\left(c .10^{9} \mathrm{cfu} / \mathrm{ml}\right)$. The suspension was vortex-mixed for $60 \mathrm{~s}$ and left for phase separation for $30 \mathrm{~min}$. The aqueous phase was removed and its $\mathrm{OD}_{540}$ measured. Percentage hydrophobicity was expressed as

$$
\left(1-\frac{\mathrm{OD}_{540} \text { after phase separation }}{\mathrm{OD}_{540} \text { of original suspension }}\right) \times 100 \text {. }
$$

\section{Intravenous catheters}

All three types of catheters used were supplied by British Viggo: silicone elastomer, gauge 14, with barium sulphate $12 \%$ (SIL); thermoplastic polyurethane (Pellethane ${ }^{\circledR} 2363$ 90A), gauge 16 (PUR); and polyurethane coated with Hydromer ${ }^{\circledR}$, gauge 14 (HYD). Hydromer coating is a hydrogel material made by the interaction of polyvinylpyrrolidone with an isocyanate prepolymer. It is chemically bonded to the polyurethane catheter material. The Hydromer coating acts like a sponge absorbing water from the blood to provide a hydrophilic sheath around the catheter. The catheters were provided sterile and stored in plastic bags. To provide easy access for the bacteria to the whole catheter surface, the catheters were split longitudinally with a sterile scalpel and the length of the catheter was calculated to give a surface area of $1 \mathrm{~cm}^{2}$. Splitting the catheters disrupted the continuity of the Hydromer coating and, during the adherence assays, portions of the inner Hydromer layer from some of the catheters flaked off. Towards the end of the study, catheters were provided by British Viggo that had been split before coating with Hydromer; this avoided damage to the Hydromer coat and its subsequent loss.

\section{Serum treatment}

Serum was collected from four healthy volunteers and pooled. Catheter pieces were immersed in whole undiluted serum for $30 \mathrm{~min}$ at room temperature. Excess serum was shaken off the catheters before use in the adherence assays.

\section{Initial adherence}

Catheters were placed in 7-ml glass screw-capped bottles containing $2 \mathrm{ml}$ of bacterial suspension $(0 \cdot 5-1) \times$ $10^{9} \mathrm{cfu} / \mathrm{ml}$; these were placed on a rotary shaker in a $37^{\circ} \mathrm{C}$ water bath for $1 \mathrm{~h}$. Care was taken to ensure total submersion of the catheters without air bubbles. Bacterial suspensions without catheters were included as standards for the ATP bioluminescence assays. After the bacteria had been allowed to adhere, catheters were removed from the bottles and placed in glass $28-\mathrm{ml}$ containers. After washing gently three times with $10-\mathrm{ml}$ volumes of PBS, excess buffer was shaken off and the catheters assessed for bacterial attachment. The adherence experiments were done in duplicate for each strain on at least two occasions.

\section{Assessment of bacterial attachment}

Bacterial attachment was assessed quantitatively by ATP bioluminiscence and by culture after ultrasonication. Scanning electronmicroscopy (SEM) was used for qualitative assessment of adherence.

ATP bioluminescence. The method used was a modification of that of Ludwicka et al. (1985). Catheter pieces were placed in small plastic capules and $200 \mu \mathrm{l}$ of trichloroacetic acid $2.5 \% \mathrm{w} / \mathrm{v}$ was added; this released bacterial ATP and inactivated ATP-degrading enzymes. A blank control was prepared at the same time with $50 \mu \mathrm{l}$ of PBS instead of the catheters. After mixing, a 50- $\mu$ l sample was transferred to a plastic cuvette and $1 \mathrm{ml}$ of ATP-monitoring reagent (LKB-Wallac 1243-200, 1 vial reconstituted with $50 \mathrm{ml}$ of Tris-EDTA buffer, $\mathrm{pH} 7.75$ ) was added. The light generated was assayed by a LKB 1250 Luminometer. To calculate the amount of ATP in each sample, $20 \mu \mathrm{l}$ of ATP standard (LKB-Wallac 1243$201 ; 1$ vial reconstituted with $10 \mathrm{ml}$ of Tris-EDTA buffer) was then added to each sample, and the increase in light emission measured. The amount of ATP was calculated by dividing the light generated by the bacterial ATP $\left(\mathrm{mV}_{\text {bact }}\right)$ by that generated by the bacterial ATP in the standard (20- $\mu$ l standard contains $0 \cdot 2 \mathrm{nmol})$. The result obtained with the blank (calculated in the same way) was subtracted from this to obtain the true value.

$$
\operatorname{ATP}(\text { nmoles })=\left[\frac{\mathrm{mV}_{\text {bact }}}{\mathrm{mV} \text { bact }+ \text { stand }}\right] \times 0.02-\text { blank }
$$

The ATP content of a 50- $\mu$ l sample of the blank control suspension (without catheters) and two ten-fold dilutions was measured for each strain. From a standard curve of ATP concentration (nmoles) against viable count it was possible to calculate the number of bacterial cells adherent to each catheter.

Culture. The catheter pieces were placed in $10 \mathrm{ml}$ of PBS in a glass 28- $\mathrm{ml}$ container and sonicated at $12 \mathrm{~m}$ (peak-to-peak) for $3 \mathrm{~min}$, in an ultrasonic disintegrator (MSE); $1 \mathrm{ml}$ of each of three ten-fold dilutions was used to make pour-plates with nutrient agar. After incubation for $18 \mathrm{~h}$ at $37^{\circ} \mathrm{C}$, colonies were counted to estimate the number of $\mathrm{cfu} / \mathrm{ml}$ and the $\mathrm{cfu} / \mathrm{cm}^{2}$ of catheter was then calculated. 
Scanning electronmicroscopy. Immediately after washing, the catheter pieces were fixed in gluteraldehyde $3 \%$ $\mathrm{v} / \mathrm{v}$ in sodium cacodylate buffer $(300 \mathrm{mOsm}, \mathrm{pH} 7.4)$ for at least $24 \mathrm{~h}$ at room temperature. The catheters were then washed in the same buffer, dehydrated through increasing ethanol concentrations and critical-point dried in a Polaron E-3000 drier with liquid $\mathrm{CO}_{2}$. After drying, the catheters were fastened with double-sided sellotape and coated with gold for $3 \mathrm{~min}$ in a sputter coater (Edwards S150) with a gold-plated cathode at $50 \mathrm{~mA}$ in an atmosphere of argon for examination in a scanning electronmicroscope (Philips 50) at $15 \mathrm{kV}$ with $45^{\circ}$ tilt. The catheter surfaces were examined for adherent bacteria and surface irregularities.

\section{Statistics}

Results were compared by the Student's $t$ test and, where appropriate, by paired $t$-tests.

\section{Results}

\section{Comparison of the bioluminescence assay and culture}

There was good agreement between the ATP bioluminescence assay and culture after ultrasonication (correlation coefficient, $r=0.62$ ). The correlation between the two assay systems is shown in fig. 1. The results of culture were slightly lower than those of the ATP assays, especially for polyurethane catheters.

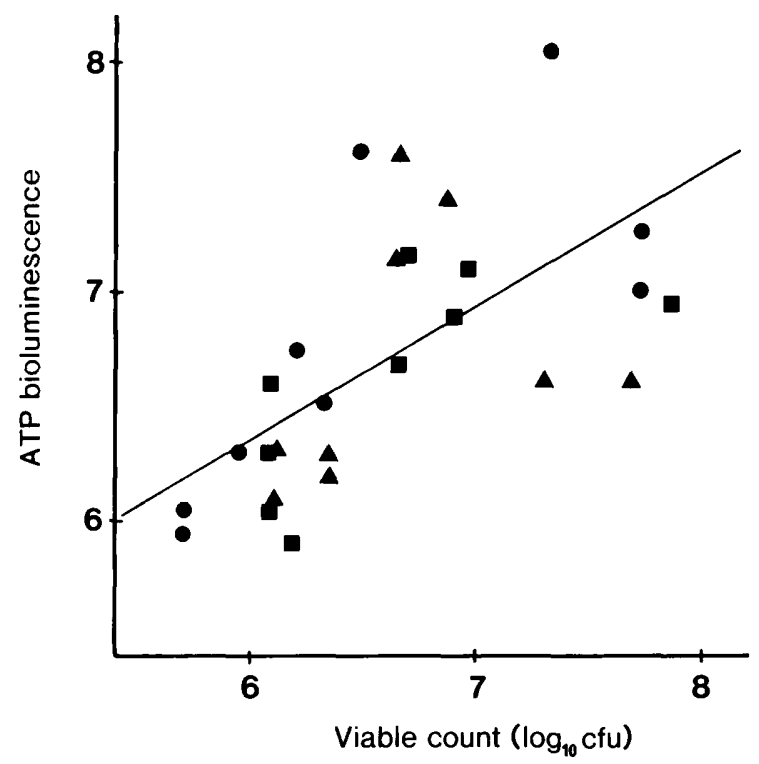

Fig. 1. Correlation of measurements of bacterial adhesion as determined by ATP bioluminescence and by culture after ultrasonication, of nine strains of staphylococci adhering on polyurethane $\boldsymbol{O}$, silicone $\boldsymbol{\Delta}$, and Hydromer-coated $\mathbf{D}$ catheters. The regression line shown, which relates culture and ATP bioluminescence, was calculated from correlation coefficient data.

\section{Adherence to different catheter materials}

Conventional catheters. There was great strain-tostrain variation and, although the bacteria appeared to adhere better to polyurethane than to other catheters when measured by ATP bioluminescence, the difference was not statistically significant (fig. 2). With some of the Hydromer-coated catheters, the damaged lining on the inside of the catheters flaked off while on the rotary shaker. This was confirmed by electronmicroscopy. The results obtained by culture after ultrasonication were slightly lower than those obtained by the ATP bioluminescence assays, especially with the polyurethane catheters.

Serum-treated catheters. Exposure of catheters to serum resulted in a significant reduction in bacterial adherence to all types of catheter, when adherence was measured by culture after sonication (mean adherence $4 \times 10^{6} \mathrm{cfu}$ versus $1 \times 10^{5} \mathrm{cfu}, \mathrm{p}<0.001$; fig. 3). When, however, adherence was measured by ATP bioluminescence (data not shown in figs.), the reduction in bacterial adherence (significance analysed by paired $t$-tests) was significant for polyurethane catheters $\left(1 \cdot 1 \times 10^{7}\right.$ cfu versus $3 \cdot 2 \times$ $\left.10^{6} \mathrm{cfu}, 0.025<\mathrm{p}<0.05\right)$ but not for silicone $(5 \times$ $10^{6}$ cfu versus $\left.1.9 \times 10^{6} \mathrm{cfu}, 0.05<\mathrm{p}<0 \cdot 1\right)$ or Hydromer-coated catheters $\left(6 \cdot 3 \times 10^{6} \mathrm{cfu}\right.$ versus $1 \times$ $\left.10^{7} \mathrm{cfu}, 0 \cdot 2<\mathrm{p}<0 \cdot 25\right)$.

Because of this inconsistency the effects of serum

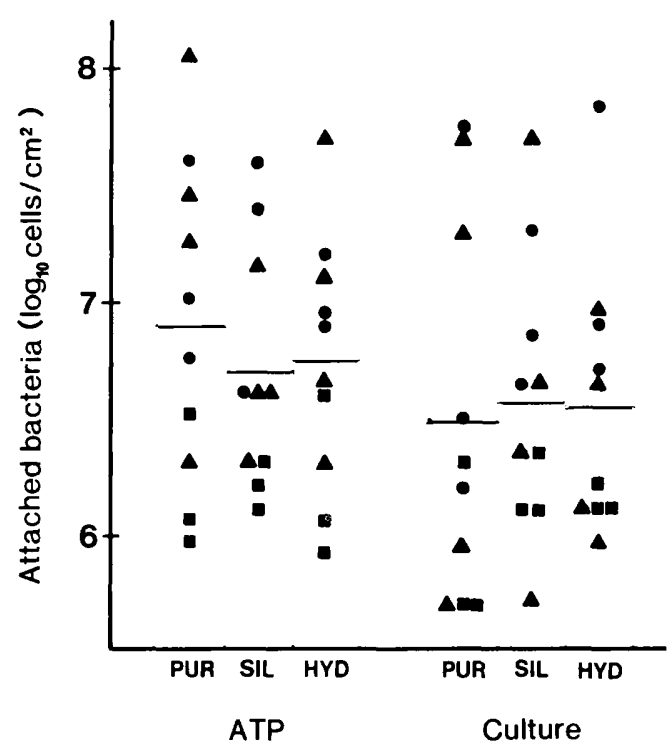

Fig. 2. Adherence of ten stains of staphylococci to polyurethane (PUR), silicone (SIL) and Hydromer-coated polyurethane (HYD) catheters measured by ATP bioluminiscence and by culture after sonication. Strains of S. aureus, ; slime-producing CNS, $\triangle$; slime non-producing CNS, $\square$. The bars indicate the mean adherence. 


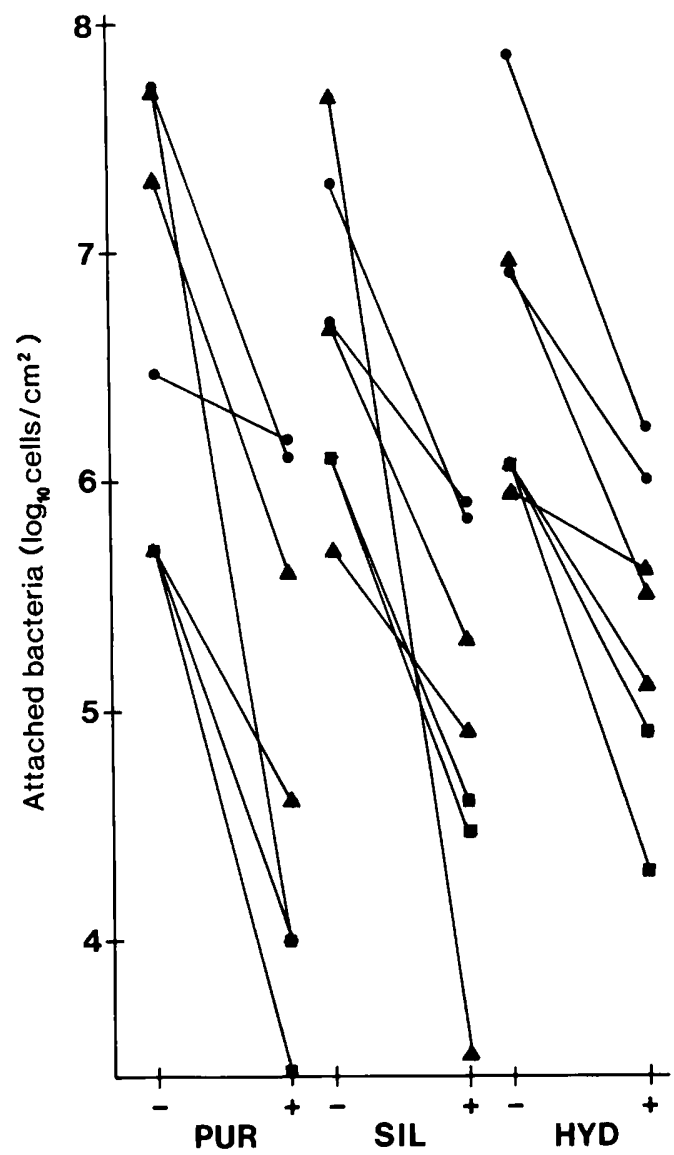

Fig. 3. Mean reduction in adherence by precoating catheters with whole serum and measuring the attached bacteria by culture after sonication. Conventional untreated catheters, - ; serum-treated catheters, + . Strains of $S$. aureus, $\bigcirc$; slimeproducing CNS, $\boldsymbol{\Lambda}$; slime non-producing CNS, on ATP bioluminescence were assessed. Incubation of staphylococci with serum for $\geqslant 30 \mathrm{~min}$ increased their ATP content slightly; it then remained stable (fig. 4) rather than decreasing, as it did when serum was not present.

Precut completely Hydromer-coated catheters. The Hydromer coat did not flake off these catheters and the bacteria adhered significantly less well to be Hydromer-coated catheters $(\mathrm{t}=2 \cdot 6, \mathrm{DF}=6, \mathrm{p}<$ 0.05 ), as measured by ATP bioluminescence (fig. 5), despite the surface area being increased by the fluid expansion of the Hydromer coating.

\section{Adherence by different bacterial strains}

When assessed by ATP bioluminescence, $S$. aureus and slime-producing strains of $S$. epidermidis adhered significantly better to the three types of catheters than did non-slime-producing $S$. epidermidis strains $(\mathrm{p}<0.01)$ (fig. 6). The results of culture after ultrasonication (not shown) were similar.

\section{Hydrophobicity}

All strains of $S$. epidermidis were very hydrophilic (i.e., hydrophobicity $0-6.5 \%$ ) whereas the three $S$. aureus strains were relatively more hydrophobic (i.e., hydrophobicity $20-23 \%$ ). The ability to produce slime did not appear to influence the hydrophobicity of $S$. epidermidis (table ).

\section{Correlation of hydrophobicity with adherence}

Overall, there was no correlation between bacterial hydrophobicity and adherence. The relatively

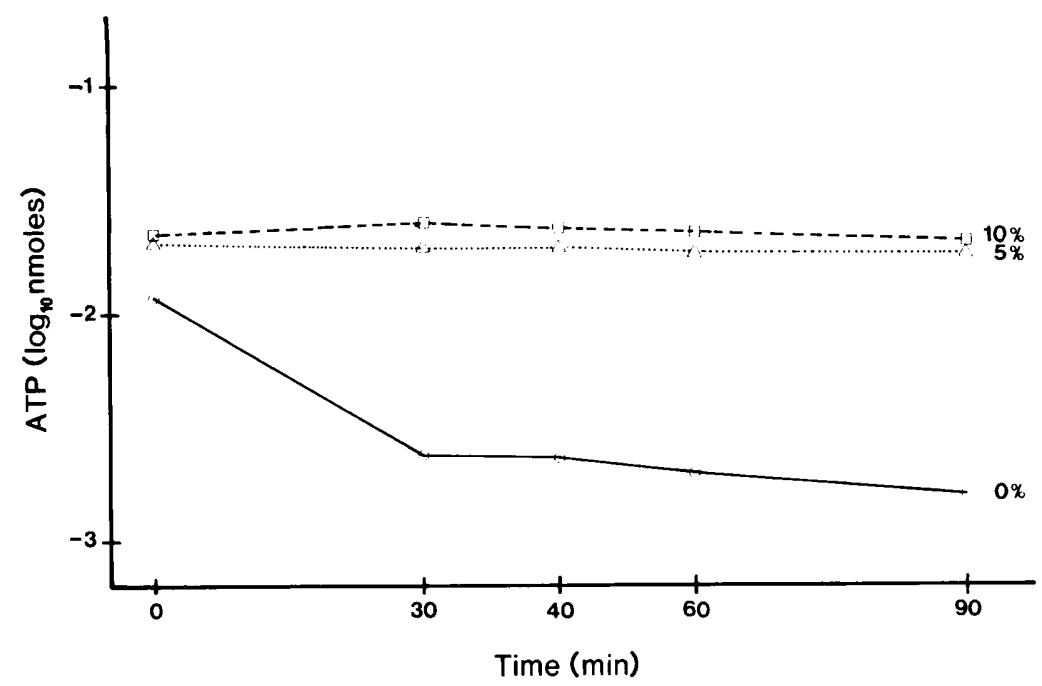

Fig. 4. ATP content of $S$. epidermidis after incubation in PBS supplemented with whole serum (5 and $10 \%)$ and without $(0 \%)$ serum. 


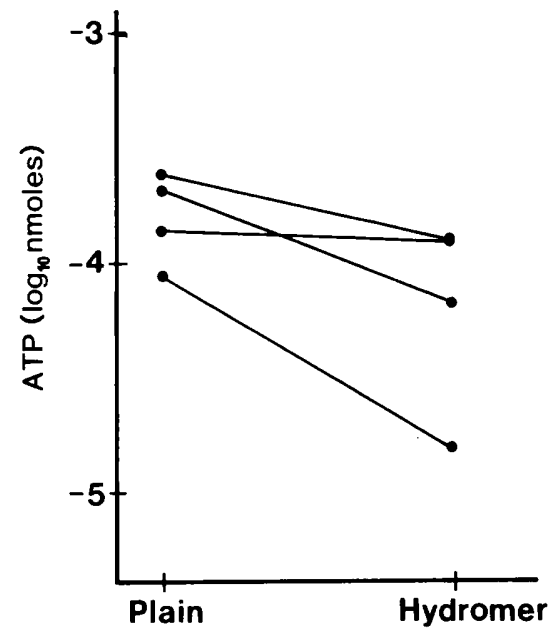

Fig. 5. Comparison of adherence (measured by ATP bioluminescence) of staphylococci on to plain and Hydromer-coated polyurethane catheters.

hydrophobic strains (C710, C1583 and C1662) adhered very well to all catheters; however, some very hydrophilic strains (e.g., C362 and C1543, both producing slime) also adhered extremely well.

\section{Scanning electronmicroscopy}

When catheter surfaces were examined by SEM there were marked differences in appearance. Polyurethane catheters were smooth and even with very few surface irregularities (fig. 7); silicone catheters had a rough surface and holes were common (figs. 8 and 9). Catheter surfaces coated with Hydromer had a wavy, crater-like appearance

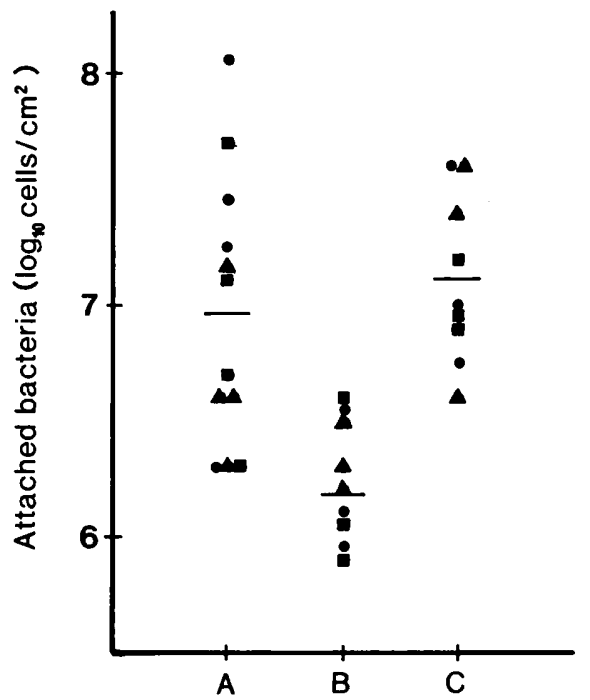

Fig. 6. Comparison of adherence (measured by ATP bioluminescence) of four slime-producing $S$. epidermidis strains (A), three slime non-producing $S$. epidermidis strains (B), and three $S$. aureus (C) strains to three types of catheter: PUR $\bigcirc$ SIL $\mathbf{A}$; and HYD

(fig. 10). The Hydromer was examined only in this dry state after it had been soaked with liquid and then dried. It was difficult to find bacteria on intact Hydromer-coated surfaces, but they were abundant where the Hydromer coating had flaked away. The $S$. aureus and slime-producing $S$. epidermidis strains tested adhered preferentially in sheets or clusters (fig. 7); the non-slime-producing strains adhered as single cells. Almost all holes and irregularities were filled with bacterial cells (fig. 9). Some of the cells

Table Slime production, hydrophobicity and adherence (measured by ATP bioluminescence) of the staphylococcal strains investigated

\begin{tabular}{|c|c|c|c|c|c|c|}
\hline \multirow[b]{2}{*}{ Species } & \multirow[b]{2}{*}{ Strain no. } & \multirow{2}{*}{$\begin{array}{c}\text { Slime } \\
\text { production }\end{array}$} & \multirow{2}{*}{$\begin{array}{c}\text { Hydrophobicity } \\
(\%)\end{array}$} & \multicolumn{3}{|c|}{ Adherence $\left(\mathrm{cfu} \times 10^{6} / \mathrm{cm}^{2}\right)$ to } \\
\hline & & & & PUR* & SIL & HYD \\
\hline S. aureus & $\mathrm{C} 710$ & $\ldots$ & 20 & 10 & 4 & 9 \\
\hline S. aureus & $\mathrm{C} 1583$ & $\ldots$ & 23 & $5 \cdot 6$ & 26 & 15 \\
\hline S. aureus & $\mathrm{C} 1662$ & $\ldots$ & 22 & 40 & 40 & 8 \\
\hline S. epidermidis & C988 & - & 3 & $1 \cdot 1$ & $1 \cdot 2$ & $1 \cdot 1$ \\
\hline S. epidermidis & $\mathrm{C} 1276$ & - & 6 & 3 & $1 \cdot 5$ & 0.8 \\
\hline S. epidermidis & A2057 & - & 6 & 0.9 & 2 & 4 \\
\hline S. epidermidis & $\mathrm{C} 362$ & + & 6 & 18 & 4 & 2 \\
\hline S. epidermidis & A1085 & + & 0 & 2 & 1.9 & $4 \cdot 7$ \\
\hline S. epidermidis & C 1543 & + & 0 & 112 & 14 & 13 \\
\hline S. epidermidis & KH11 & + & 6 & 28 & 4 & 52 \\
\hline
\end{tabular}

* Catheters were of polyurethane (PUR), silicone (SIL) or Hydromer-coated polyurethane (HYD) (see Materials and methods).

$\ldots=$ Not relevant. 


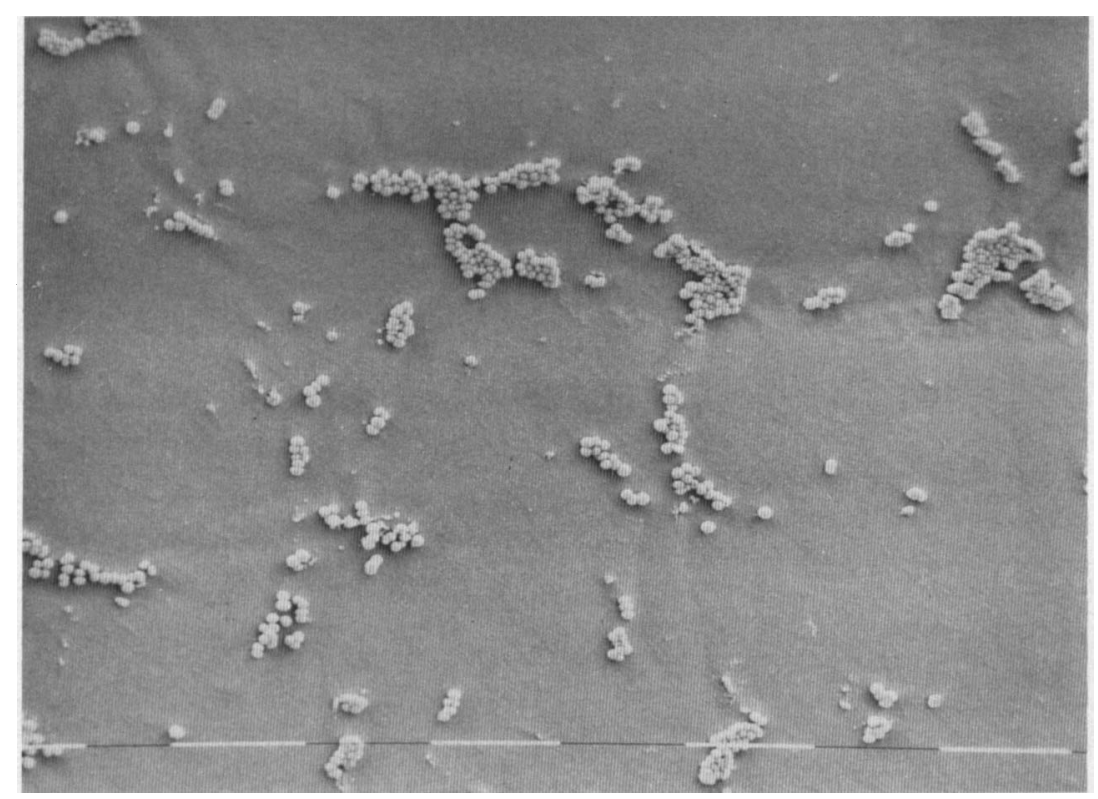

Fig. 7. S. aureus strain C1583 adhering to surface of polyurethane catheter (bars $=10 \mu \mathrm{m}$ ).

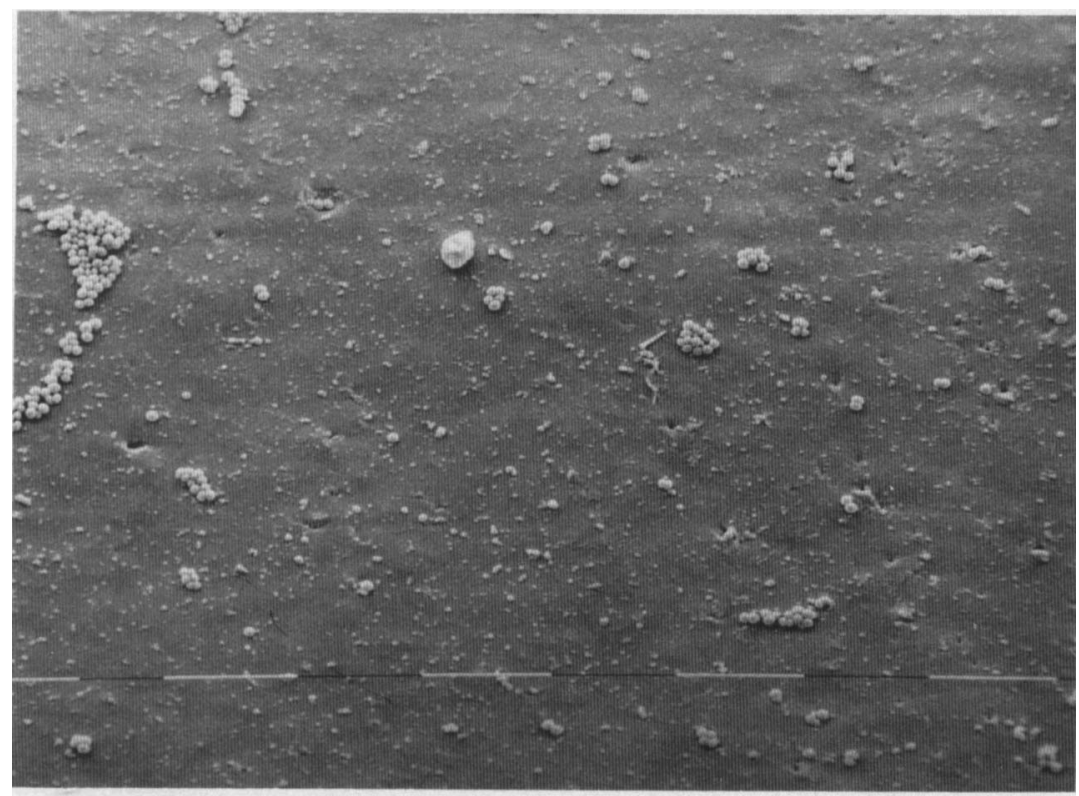

Fig. 8. S. aureus strain C1583 adhering to surface of silicone catheter (bars $=10 \mu \mathrm{m})$.

appeared to attach themselves by means of projections from the cells to the catheter surface (fig. 11).

\section{Discussion}

Bacterial biomass adherent to prosthetic materials can be measured by direct microscopy (Hogt et al., 1986), by quantitative culture (Sheth et al., 1983; Mackenzie and Rivera-Calderon, 1985), by use of radiolabelled bacteria (Pascual et al., 1986) or by assay of ATP by bioluminescence (Harber $e t$ al., 1983). Each method has some disadvantages, but ATP bioluminescence provides a rapid and simple quantitative assay of bacterial biomass 


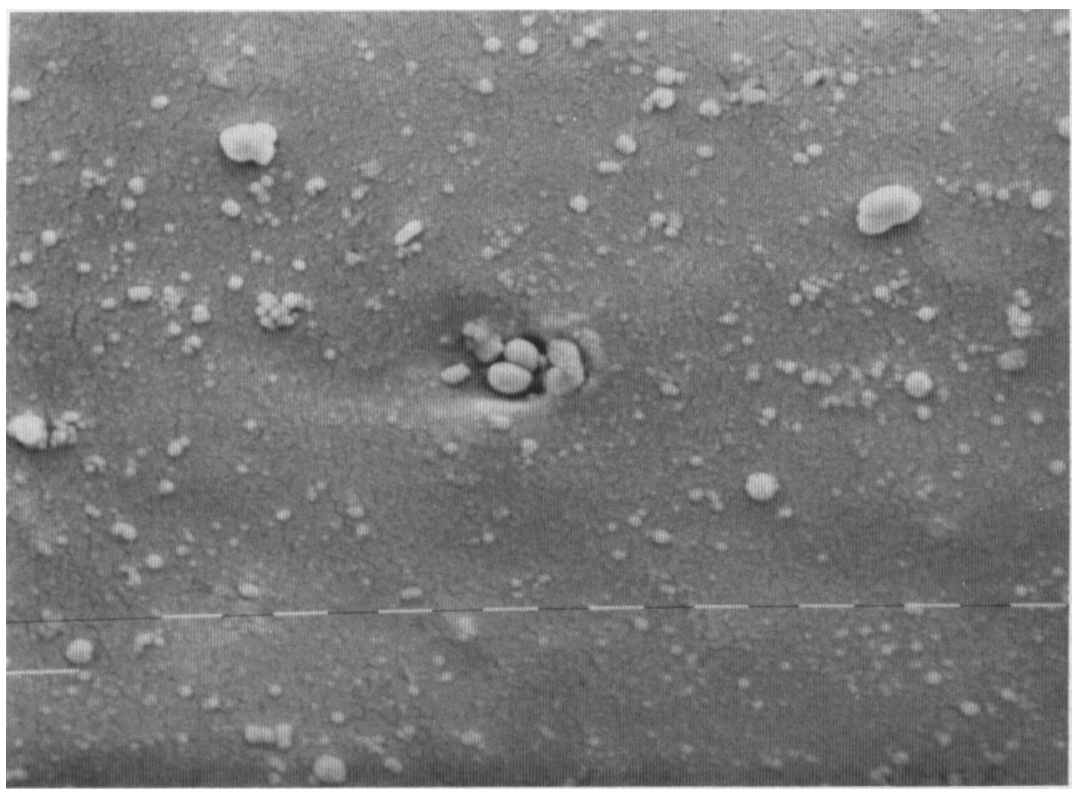

Fig. 9. Surface of silicone catheter demonstrating its rough surface and adherent bacteria of $S$. epidermidis strain A2057 (bars $=1 \mu \mathrm{m}$ ).

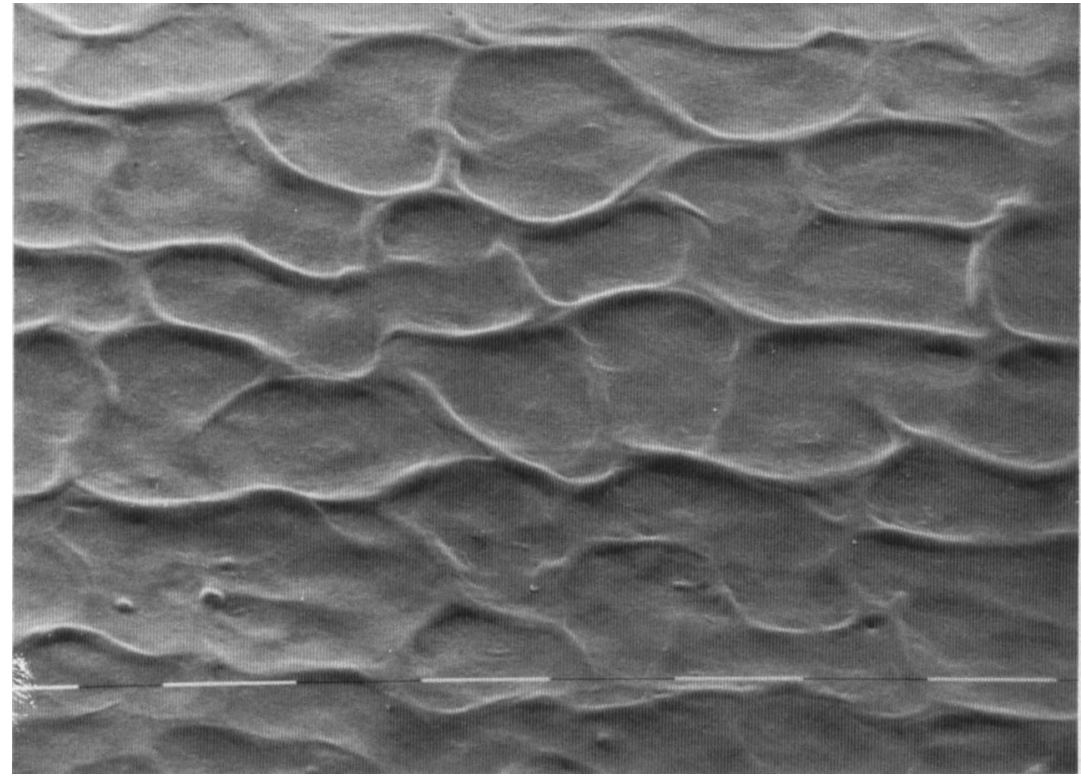

Fig. 10. Surface of Hydromer-coated polyurethane catheter (bars $=10 \mu \mathrm{m}$ ).

attached to synthetic polymer surfaces (Ludwicka et al., 1985). The latter method was modified to measure the number of bacteria attached to commercially produced catheter tubing, and the results correlated well with results obtained by culture after ultrasonication. Culture gave slightly lower results than the ATP assay, particularly with polyurethane catheters to which bacteria may have adhered more avidly so that the degree of ultrasonication was insufficient to remove all adherent cells from the catheter surface; alternatively, adherent cells may have slightly higher ATP content than cells in suspension. The discrepancy between methods was much more marked with serumtreated catheters; this was found to be because serum increased the ATP content of the bacterial 


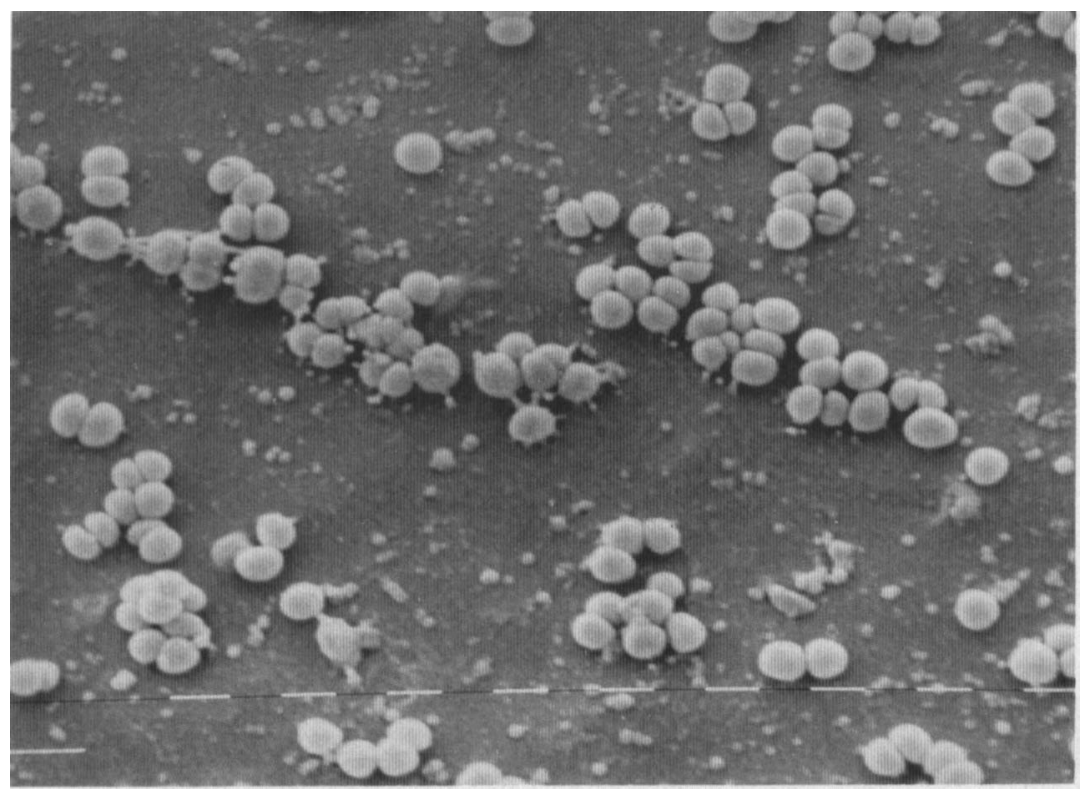

Fig. 11. S. epidermidis strain A2057 adhering to surface of silicone catheter (bars $=1 \mu \mathrm{m}$ ).

cells. The ATP content remained almost constant up to $90 \mathrm{~min}$ whereas that of the cells in buffer without serum declined significantly. Therefore, measurement of cells adherent to serum-treated catheters by ATP bioluminescence produces spuriously high results.

SEM showed that fewer organisms adhered to the Hydromer coating than to other surfaces, a finding that contradicted the results of the initial quantitative assays. However, in some of the initial assays the damaged Hydromer coating on the inside of the catheters flaked off leaving exposed areas of polyurethane and there were more bacteria adherent to the exposed surfaces than to Hydromer coating. Therefore, catheters coated with $\mathrm{Hy}$ dromer after they had been cut were obtained from the manufacturer and compared with uncoated catheters. This time ATP bioluminescence showed significantly less adherence to the Hydromer-coated catheters, despite the increase in surface area caused by the fluid soaking of the Hydromer coat. The mean adherence of all strains to silicone, polyurethane and "damaged" Hydromer catheters was not statistically different.

There was wide strain-to-strain variation in bacterial adherence. $S$. aureus and slime-producing $S$. epidermidis strains adhered significantly better to all catheters than did the non-slime-producing $S$. epidermidis strains. This is in agreement with the findings of Christensen et al. (1985) who found a good correlation between slime production and adherence. Conversely, Pascual et al. (1986) found that slime-producing CNS adhered less quickly and less strongly than other CNS, but they incubated their catheters without shaking. The stress or challenge of shaking demonstrates differences in adherence between slime-producing and non-producing strains (Kristinsson et al., 1987).

Bacterial adherence to prosthetic biomaterials or plastics is poorly understood. It depends upon attracting and repelling forces between the two surfaces and it might be thought that hydrophobic bacteria would be rejected from aqueous fluids and attracted towards non-aqueous phases, e.g., solid surfaces (Marshall, 1985). All strains tested were hydrophilic $(0-23 \%)$ and it is likely that growth in TSB enhances production of hydrophilic sites on the surface of staphylococci. There was no correlation between hydrophobicity and adherence, but this narrow hydrophobicity range makes correlation more difficult. Reifsteck et al. (1987) investigated the hydrophobicity-hydrophilicity of staphylococci but included only one strain of $S$. epidermidis, and found only slight correlation between hydrophobicity and adherence to silicone catheters. Pascual et al. (1986) found a significant positive correlation between hydrophobicity and adherence and concluded that hydrophobicity played a powerful role, but Hogt et al. (1985) concluded that adherence was not related to hydrophobicity. However, each study used different catheter materials and different methods. Furthermore growth of bacteria in different media changed their hydrophobicity (Ljungh et al., 1985); there- 
fore, to relate hydrophobicity and adherence, cells must be grown in the same medium and conditions for both tests. Pascual et al. (1986) used cells grown in Mueller-Hinton broth for adherence assays but in TSB for the hydrophobicity tests; information is lacking from Hogt et al. (1985).

Measuring bacterial adherence to clean catheters is an over-simplification of events in vivo. Much of the catheter surface is coated within seconds with body fluids and proteins, followed by platelets and fibrin. Once coated, the catheter material makes little difference to bacterial adherence, but initial adherence may depend on the catheter material. Coating the catheters with serum, intended to imitate those conditions, led to a significant decrease in bacterial adherence to all catheters,

\section{REFERENCES}

Borow M, Crowley J G 1985 Evaluation of central venous catheter thrombogenicity. Acta Anaesthesiologica Scandinavica 81 Suppl: 59-64.

Christensen G D, Simpson W A, Bisno A L, Beachey E H 1982 Adherence of slime-producing strains of Staphylococcus epidermidis to smooth surfaces. Infection and Immunity 37 : 318-326.

Christensen G D et al. 1985 Adherence of coagulase-negative staphylococci to plastic tissue culture plates: a quantitative model for the adherence of staphylococci to medical devices. Journal of Clinical Microbiology 22: 996-1006.

Harber M J, MacKenzie R, Asscher A W 1983 A rapid bioluminescence method for quantifying bacterial adhesion to polystyrene. Journal of General Microbiology 129: 621632.

Harvey M P, Trent R J, Joshua D E, Ramsey-Stewart G, Storey D W, Kronenberg H 1986 Complications associated with indwelling venous Hickman catheters in patients with hematological disorders. Australian and New Zealand Journal of Medicine 16: 211-215.

Hogt A H, Dankert J, Feijen J 1985 Adhesion of coagulasenegative staphylococci with different surface characteristics onto a hydrophobic biomaterial. Antonie van Leeuwenhoek 51: $510-512$.

Hogt A H, Dankert J, Hulstaert C E, Feijen J 1986 Cell surface characteristics of coagulase-negative staphylococci and their adherence to fluorinated poly(ethylenepropylene). Infection and Immunity 51 : 294-301.

Hoshal V L, Ause R G, Hoskins P A 1971 Fibrin sleeve formation on indwelling subclavian central venous catheters. Archives of Surgery 102 : 353-358.

Kristinsson K G, Jones G I, Oxley K M, Hastings J G M 1987 Rapid assay of staphylococcal adhesion to plastic microtitration trays. Journal of Medical Microbiology 24: vi (abstract).

Ljungh A, Hjerten S, Wadstrom T 1985 High surface hydrophobicity of autoaggregating Staphylococcus aureus strains isolated from human infections studied with the salt aggregation test. Infection and Immunity 47: 522-526.

Ludwicka A, Switalski L M, Lundin A, Pulverer G, Wadstrom T 1985 Bioluminescent assay for measurement of bacterial attachment to polyethylene. Journal of Microbiological Methods 4: 169-177. confirming the results of Hogt et al. (1985) and Pascual et al. (1986).

Assay of bacterial biomass by ATP bioluminescence makes it feasible to compare bacterial adherence to different catheters, but the present method is cumbersome for testing large numbers of strains under different conditions. More rapid methods, based on a microtitration format now being developed, will enable in-vitro evaluation of bacterial adherence to new catheter materials before clinical trials.

I thank Mr T. E. Durrant, Department of Pathology for excellent assistance with the SEM studies, Drs J. G. M. Hastings and R. C. Spencer for helpful advice, and British Viggo for supplying the catheters.

MacKenzie A M R, Rivera-Calderon R L 1985 Agar overlay method to measure adherence of Staphylococcus epidermidis to four plastic surfaces. Applied and Environmental Microbiology 50: 1322-1324.

Marshall K C 1985 Mechanisms of bacterial adhesion at solidwater interfaces. In: Savage D C, Fletcher M (eds) Bacterial adhesion, mechanisms and physiological significance. Academic Press, New York, pp 133-162.

Pascual A, Fleer A, Westerdaal N A C, Verhoef J 1986 Modulation of adherence of coagulase-negative staphylococci to teflon catheters in vitro. European Journal of Clinical Microbiology 5: 518-522.

Peters G, Locci R, Pulverer G 1982 Adherence and growth of coagulase-negative staphylococci on surfaces of intravenous catheters. Journal of Infectious Diseases 146: 479-482.

Press O W, Ramsey P G, Larson E B, Fefer A, Hickman R O 1984 Hickman catheter infections in patients with malignancies. Medicine 63: 189-200.

Reifsteck F, Wee S, Wilkinson B J 1987 Hydrophobicityhydrophilicity of staphylococci. Journal of Medical Microbiology 24 : 65-73.

Rosenberg M 1984 Bacterial adherence to hydrocarbons: a useful technique for studying cell surface hydrophobicity. FEMS Microbiology Letters 22: 289-295.

Sattler F R, Foderaro J B, Aber R C 1984 Staphylococcus epidermidis bacteremia associated with vascular catheters: an important cause of febrile morbidity in hospitalised patients. Infection Control 5: 279-283.

Seifert L M, Greer R T 1985 Evaluation of in-vivo adsorption of blood elements on to hydrogel-coated silicone rubber by scanning electron microscopy and fourier transform infrared spectroscopy. Journal of Biomedical Materials $R e-$ search 19: 1043-1071.

Sheretz R J, Falk R J, Huffman K A, Thomann C A, Mattern W D 1983 Infections associated with subclavian Uldall catheters. Archives of Internal Medicine 143: 52-56.

Sheth N K, Rose H D, Franson T R, Buckmire F L A, Sohnle $P$ G 1983 In-vitro quantitative adherence of bacteria to intravascular catheters. Journal of Surgical Research 34: 213-218.

Stenqvist O, Curelaru I, Linder L-E, Gustavsson B 1983 Stiffness of central venous catheters. Acta Anaesthesiologica Scandinavica 27: 153-157. 